\title{
Executive Behaviour- the Bhagavad Gita Way
}

\author{
T. S. Balakrishnan, \\ Research Scholar, Dept of Management Studies, St. Peter's University, Chennai,
}

\begin{abstract}
The trait theory is the most basic and one of the important theories of leadership. But these traits become meaningful only when they are reflected in the actual behaviour of the executive. The Bhagavad Gita, written more than five thousand years ago is not just a spiritual text; it is also a book on management. A proper study of the Gita would reveal that an executive would be much benefited by an in depth study of the Gita. The present paper is about executive behaviour as envisaged by Bhagavad Gita. An executive should always focus on the performance of his duties without being anxious about the results. He should own full responsibility for all his actions and omissions. An executive should neither eat too little or too much; sleep too much or sleep too little and should be moderate in his relaxation or pastimes. An Executive should perform all his duties to the best of his ability and leave the rest to the wisdom of the top management.
\end{abstract}

Key Words: Trait Theory, Bhagavad Gita, Role Model, Stress, Job Description, Job Specification

\section{Introduction}

Among the various theories of leadership, trait theory is the most basic and one of the important theories of leadership. But the leadership traits enshrined in the trait theory become meaningful only when they are translated into action. In other words, whatever traits or qualities that have been described therein will yield results only when they are translated into action. The executives achieve optimum performance only by positive behaviour and effective communication. It naturally follows that the success or failure of executives largely depends upon their behaviour. And again that is the reason why the study of Organisational Behaviour is essential for a proper administration of business houses. In this paper an attempt is made to study the ideal behaviour of an executive as advocated by the Bhagavad Gita.

\section{The Bhagavad Gita}

The Bhagavad Gita, written more than five thousand years ago is not just a spiritual text; it is also a book on management. And probably, it is the first ever book written on management. The Gita is essentially a dialogue between Prince Arjuna and Lord Krishna. This great work of Saint Vyasa consists of 18 chapters and 700 slokas or stanzas. And like the Holy Bible, the Bhagavad Gita has been also translated into all major languages of the world. The Gita is a repository of management principles and practices. A proper study of the Gita would reveal that an executive would be much benefited by an in depth study of this great and ancient text. There are several books written on 'Gita and Management'. The author has done a research on Bhagavad Gita treating it as a source for Executive Development. And based on the research findings a development manual was prepared consisting of eleven modules. The present paper is about executive behaviour as envisaged by Bhagavad Gita.

\section{Bhagavad Gita on Executive Behaviour}

The need for a senior executive is felt only in the presence of serious problems. The executives who get such challenging opportunities should be really happy so that they can prove their mettle. And an executive who avoids such challenges loses his reputation fast not only in his own organization and also elsewhere. The reputation of executives who face challenges boldly will go very high among CEOs of companies of repute, which will bring more opportunities for advancement of their career. An executive should always concentrate on the performance of duties without being anxious about the results. This attitude will relieve him of all anxieties and tensions about the results of whatever actions he does. Swami Chinmayananda ${ }^{1}$, in his inimitable style says 'These musings should not be our anxiety- they are idle dissipations that will puncture our efficiencies and flatten our abilities to serve in our chosen field'. Excellence in action means doing the assigned work to the best of one's ability without worrying about the results. Such worry and anxiety would dilute the effectiveness of the executive's action. Further this message is also an antidote to stress.

In every organization we find two types of executives: some of them are adepts in executing managerial decisions and the others are experts in formulating plans, policies and programmes. Therefore each executive will have to choose the jobs that are best suited to him. Executives should be role models to their subordinates and should be always outstanding and careful about their behavior and conduct. The reason is that the senior executives are always held as the role models by their subordinates and are emulated by them. 'In 
public interest, a person of eminence has therefore to put forth his best' says Swami Chidbhavananda ${ }^{2}$. Every executive should strictly adhere to the job allotted to him and should avoid poking his nose into the other man's job. An Executive should own full responsibility for all his actions and omissions

An executive attains excellence in his career only when he looks with equal regard upon well-wishers, friends, enemies, his own kith and kin and all others. A manager or leader can achieve success only when he is moderate in food, sleep and recreation. All the powers exercised by the various executives or employees are derived from the organization. Further as pearls are strung through the string everything is based on the organization. In sum the organization is the seed of all. The executive should constantly remember the organization, and also bear in his mind the interest and growth of it while engaging himself in the discharge of his organizational responsibilities. An ideal executive shall fix his mind on the organization, devoted to it, do everything as an offering to it and hold his organization in high esteem. An organization would have earned a great name or reputation in the industry because of the quality of its products, service to the customers, its social commitment and scores of other reasons. An executive should endeavor to know them all and do his best to further enhance the name and fame of his organization.

The Executive should be aware of the fact that throughout the various branches, departments and divisions the organization is present. He should not even for a moment feel that the organization is not present in a small rural branch. An organization is present wherever an employee is doing any organizational work; it may be the factory, a small rural branch, the international office or the head office. This is seeing unity in diversity. Whether a function is that of the CEO, Manager, Supervisor or an operator, ultimately it is the organization which is doing or gaining or losing anything because of that activity. Every executive should look at every employee as an extension or expansion of the organization and therefore treat every employee with grace and respect. When the executive recruits men and women for his organization he should scan the characteristics of the candidates and decide about the selection based on the job description and job specification of the particular job.

The executive should be always aware of the fact that he exercises his powers through the authority conferred on him by the organization. Further all the funds of the organization must be utilized only for organizational purposes. The organization is the ultimate and any other person's stay in the organization, whatever be his designation, is impermanent. An executive should choose such a food which strengthens the mind as well as the body. It is such type of food that builds life, purity, strength, health, joy, cheerfulness and appetite which an executive should take. Paramahamsa Yogananda asserts 'What we eat is important because it has both physical and mental consequences'. An executive, as long as he is employed in an organization, will have to perform all of his duties in such a way that there is inner harmony or peace throughout the performance of such actions.

The life of an executive is never a bed of roses. He has to struggle a lot and therefore it will be definitely unpleasant or bitter in the beginning but towards the end he will have very pleasant or sweet experiences. The executive should choose jobs or assignments which are dictated by his inner calling and basic traits. Every executive has his own well defined role to play and duties to perform. It is always better and safer to confine to one's own role or duties. Likewise, it is risky or dangerous to poke one's nose into another man's area or activity. When the executive is always focused on the origination and its growth and prosperity and works hard the inevitable consequence is that the origination would recognize him and reward him with suitable monetary benefits and promotions.

One should live for the sake of others and their peace. Man commits sins because of his desire and passion and when the desire is blocked he is overcome by anger. And this lust or desire is never satisfied or extinguished and it burns like a fire. Acquiring detachment in action is the very essence of spiritual life. An executive, if he wants to be really effective should have self regulation and practise meditation regularly. An executive should neither eat too little or too much; sleep too much or sleep too little and should be moderate in his relaxation or pastimes.

A dedicated executive disregards all the rewards promised in the terms of appointment and attains the highest position in the organisation by his steadfast devotion to the organisation and hard work. Austerity of deed consists of the worship of gods, the priest, the guru, and the wise; purity, honesty, celibacy and nonviolence.

Human mind is indeed unsteady and turbulent but it can be controlled by constant practice and dispassion. When a person performs all his prescribed duties but at the same time renounces all attachment to the fruits thereof, it is called as Sathvic renunciation. An Executive should perform all his duties and leave the rest to the wisdom of the top management. He should develop a spirit of detachment towards the fruits of his actions or performance.

The knowledge by which one sees the undivided divinity in all creatures is Sathvic. In the same way an executive should see the undivided entity of the organisation in all the employees. An Executive can attain the 
highest perfection by devotion to one's assigned duties or job description. He will make rapid progress in his career if he does this. He should not give up his duty just because it is trivial or insignificant.

\section{Conclusion}

Of the various theories of leadership, the trait theory is the most basic and important one. But these traits are of no use unless they are put into actual practice. The Bhagavad Gita which is essentially a dialogue between Prince Arjuna and Lord Krishna contains several principles of Management. The present paper is an attempt to cull out the principles of executive behaviour as envisaged by the Gita. Executives should be role models to their subordinates and should be always outstanding and careful about their behavior and conduct. To be effective an executive should always focus on the performance of his duties without being anxious about the results. Executives will have to choose the jobs that are best suited to them. An Executive should own full responsibility for all his actions and omissions. Every executive should look at every other employee as an extension or expansion of the organization and therefore treat every employee with grace and respect. A manager or leader can achieve success only when he is moderate in food, sleep and recreation and hobbies. An executive, if he wants to be really effective should have self regulation and practise meditation regularly. An Executive should perform all his duties to the best of his ability and leave the rest to the wisdom of the top management.

\section{Reference:}

[1]. Swami Chinmayananda, 'The Art of Man Making', Chinmaya Mission Trust, Mumbai, 1991, P.47

[2]. Swami Chidbhavananda, 'The Bhagavad Gita - Commentary', Sri Ramakrishna Tapovanam, 2012 , P 242.

[3]. Paramahamsa Yogananda 'God Talks with Arjuna- The Bhagavad Gita', Yogoda Satsangha Society of India, 2005, P 995 